\title{
Use of apple pomace in animal feed as an antioxidant of meat
}

\author{
A.D. Alarcon-Rojo ${ }^{1 \#}$, V. Lucero ${ }^{1}$, L. Carrillo-Lopez ${ }^{1,2}$ \& H. Janacua ${ }^{3}$ \\ ${ }^{1}$ Universidad Autónoma de Chihuahua, Facultad de Zootecnia y Ecología, México \\ ${ }^{2}$ Catedratico, Consejo Nacional de Ciencia y Tecnología, México \\ ${ }^{3}$ Universidad Autónoma de Ciudad Juárez, Departamento de Ciencias Veterinarias, México
}

(Received 5 May 2018; Accepted 27 November 2018; First published online 12 March 2019)

\author{
Copyright resides with the authors in terms of the Creative Commons Attribution 4.0 South African Licence. \\ See: http://creativecommons.org/licenses/by/4.0/za \\ Condition of use: The user may copy, distribute, transmit and adapt the work, but must recognise the authors and the \\ South African Journal of Animal Science.
}

\begin{abstract}
The experiment was aimed to evaluate the effects of dietary inclusion of fermented apple pomace (FAP) in lamb diet on physicochemical and lipid oxidation of meat during storage at $4{ }^{\circ} \mathrm{C}$. Twenty-four crossbred sheep were randomly assigned to two experimental diets with or without $11 \%$ (dry matter basis) FAP for $56 \mathrm{~d}$. The lambs were then slaughtered, and the longissimus dorsi muscle was removed 24 hours after slaughter to measure meat quality. The inclusion of FAP in the diet of sheep did not change lightness and redness of meat, but greater yellowness was observed with increased storage time. Diet did not have any influence on the $\mathrm{pH}$, water-holding capacity (WHC), drip loss (DL) and shear force of meat. Storage time increased yellowness and tenderization of meat. Oxidation of lipids in stored meat from sheep that were fed FAP was lower than that in the control group. It is concluded that the use of fermented apple pomace in the diet of sheep decreased meat oxidation during storage, without affecting other quality characteristics of the meat.
\end{abstract}

Keywords: Diet, fermented, longissimus dorsi, sheep, storage

\# Corresponding author: aalarcon@uach.mx

\section{Introduction}

Agribusinesses related to fruits and vegetables produce considerable amounts of by-products with potential for use in livestock diets (Mirzaei-Aghsaghali \& Maheri-Sis, 2008; Taasoli \& Kafilzadeh, 2008). In Mexico, the state of Chihuahua is the main producer of apples. Apple waste, as a by-product from the juice industry, represents a potential food source for animals owing to its low cost and highly fermentable nutrients. Yeasts and bacteria play a significant role in the fermentation of apple by-products (Rodriguez et al., 2017). One of these by-products is apple pomace (FAP), which has $2.37 \%$ protein and $84.7 \%$ carbohydrates (O'Shea et al., 2015), including polyphenols with antioxidant effects (Lu \& Yeap, 2000; Sudha et al., 2007; Brenes et al., 2008; Ćetković et al., 2008). FAP is obtained through a process of aerobic fermentation of apple pomace with the addition of urea, ammonium sulfate and minerals. As a result, a $25 \%$ $28 \%$ increase in crude protein is obtained (Alibes et al., 1984). This product has been used as an additive to animal feed (Díaz-Plascencia et al., 2013). FAP could be an important supplement for sheep, particularly for Katahdin, Charollais and Dorper ovine breeds, which are used for meat production in Mexico owing to their growth rate and carcass characteristics (Vázquez et al., 2011).

Many agro-industrial by-products have been added to animal diets to improve meat quality. For example, grapeseed extract improves the oxidative stability of meat (Kim et al., 2002), oregano oil delays lipid oxidation during storage (Simitzis et al., 2008), beet pulp increases meat lightness and decreases the final $\mathrm{pH}$ and cooking weight loss (Olfaz et al., 2005), olive pomace increases meat lightness without affecting redness, quebracho (Schinopsis lorentzii) increases the redness of fresh meat (Luciano et al., 2009) and fermented persimmon peel increases the lightness and redness of meat (Kim et al., 2006). However, in apple-producing areas of Mexico, apple pomace is not commonly used in the production of sheep meat, and there are no studies that have examined the effects of FAP on lamb meat quality. The hypothesis was that fermented apple pomace can be used as an ingredient in sheep diets because it improves meat 
characteristics. Therefore, this study was aimed to evaluate the effects of dietary inclusion of FAP in lamb diet on the quality parameters of meat.

\section{Materials and Methods}

A fermentation bed (1.5 $\mathrm{m}$ wide and $15 \mathrm{~m}$ long) was prepared for the production of FAP. To this bed, $1.5 \%$ urea, $0.5 \%$ of a mineral mixture and $0.4 \%$ ammonium sulfate (based on the total wet weight) were added to the apple pomace and mixed with a rototiller to allow fermentation. The bed was stirred four times during the first day of mixing and three times daily from day 2 to day 5 of fermentation to allow ventilation. On day 6 , the fermentation bed was spread on the ground to dry in the sun until it reached a dry matter content that permitted storage. The FAP that was prepared had $26 \%$ crude protein content and $13 \%$ true protein (Rodriguez et al., 2017).

Twenty-four sheep were used in this study with an average initial weight of $25.37 \pm 2.9 \mathrm{~kg}$ and final weight of $42.42 \pm 3.1 \mathrm{~kg}$, of $147 \pm 6.2$ days old, with an average cold carcass weight of $20.5 \mathrm{~kg}$. The slaughter weight was chosen to represent a range of the weight at which local animals are traditionally slaughtered. All animals were fed ad libitum a diet of alfalfa hay and $300 \mathrm{~g}$ of concentrate per animal. The sheep were randomly housed in individual cages for a 56-day feeding test. Half of the animals (12) were fed an elemental isoenergetic diet as the control, and the other half were fed diets supplemented with FAP. The diets were formulated according to the NRC (1985) for growing sheep (Gómez-Vázquez et al., 2011). The ingredients were the same in the two diets, and only the proportion changed when including FAP in the treatment diet (Table 1).

After the fattening period, animals were fasted for 24 hours and slaughtered by conventional techniques using electrical stunning. The carcasses were stored at $4{ }^{\circ} \mathrm{C}$, and 24 hours later, the longissimus dorsi muscle was obtained from the right half of the carcass. This meat portion was divided into two parts: one was stored at $-25^{\circ} \mathrm{C}$ and was used for the shear force (tenderness) analysis, and the other was used for the remaining physicochemical tests.

Table 1 Ingredients and chemical composition of experimental diets with fermented apple pomace (FAP) for the sheep used in the present experiment

\begin{tabular}{lcc}
\hline & \multicolumn{2}{c}{ Diet, $\mathbf{g} / \mathbf{k g}$ DM } \\
\cline { 2 - 3 } & Control & FAP \\
\hline Ingredient, g/kg DM & & \\
$\quad$ Alfalfa hay & 381 & 286 \\
$\quad$ Soybean meal & 124 & 94 \\
$\quad$ Corn grain, rolled & 425 & 430 \\
$\quad$ Fermented apple pomace & & 110 \\
$\quad$ Animal Fat & 20 & 20 \\
Molasses cane & 30 & 40 \\
$\quad$ Salt & 10 & 10 \\
$\quad$ Mineral premix & 10 & 10 \\
Proximal analysis & & \\
$\quad$ Dry matter & & 913 \\
$\quad$ Crude protein & 905 & 116 \\
\hline
\end{tabular}

${ }^{1}$ According to Van Soest et al. (1991)

The $\mathrm{pH}$ value was measured 24 hours after slaughter using a potentiometer (Thermo Scientific Orion 210A) in a homogenised sample of $1 \mathrm{~g}$ meat with $9 \mathrm{~mL}$ distilled water for $1 \mathrm{~min}$ (Antonomanolaki et al., 1999). WHC was determined 24 hours after slaughter using the methods reported by Tsai \& Ockerman (1981) with a modification of $0.3 \mathrm{~g}$ for the weight of the sample.

Drip loss was determined 24 hours after slaughter, using $3 \mathrm{~g}(\mathrm{Q} 1)$ of meat suspended inside a plastic container at $4{ }^{\circ} \mathrm{C}$ for 48 hours. Subsequently, the weight of the sample was recorded one more time (Q2) (Honikel \& Jim, 1986). DL was determined by calculating the weight difference before and after refrigeration. 
Colour was evaluated on days 1,4 and 7 of storage after slaughter using a HunterLab MS-S colourimeter, and the coordinates $L^{*}, a^{*}$ and $b^{*}$ were obtained (Garrido et al., 1994). Shear force was evaluated in cooked meat samples using a Lloyd Instruments TA1 Texture Analyzer Chatillon texturometer.

The degree of lipid oxidation was determined by measuring thiobarbituric acid (TBA)-reactive substances (TBARS) according to the technique described by Piccini et al. (1986). Ten $\mathrm{g}$ of muscle were homogenized (ESGE bio homogenizer model M133/1281-0; Bio Spec products Inc., Bartlesville, OK, USA) with a $10 \%$ solution of $6 \mathrm{~N} \mathrm{HCl}$ solution for 40 seconds, the resulting mixture was subjected to distillation, and $50 \mathrm{~mL}$ aliquots were collected. Afterwards, $2.5 \mathrm{~mL}$ distillate was taken and mixed with $2.5 \mathrm{~mL} 0.02 \mathrm{M}$ TBA. The mixture was incubated in a boiling water bath $\left(100^{\circ} \mathrm{C}\right)$ for $40 \mathrm{~min}$. A sample containing $2.5 \mathrm{~mL}$ distilled water and $2.5 \mathrm{~mL}$ TBA was used as a blank. Both were cooled for 10 min in running tap water and absorbance was measured at $535 \mathrm{~nm}$ on a spectrophotometer (Genesys 20, model 4001/4, Thermo Spectronic, Waltham, MA, USA). The results from the samples were plotted against a standard curve prepared with known concentrations of tetraethoxypropane. This procedure was performed in triplicate, and the results were expressed as mg malondialdehyde (MDA) per $\mathrm{kg}$ meat ( $\mathrm{mg}$ MDA/kg meat). The process was carried out in duplicate on days 1, 3, 7 and 10 after slaughter.

Data of shear force and lipid oxidation were analysed as a completely randomized design with two factors (diet and storage time) and 12 experimental units each, using SAS System (2012), whereas data of $\mathrm{pH}, \mathrm{WHC}$ and $\mathrm{DL}$ were analysed as a completely randomized design to evaluate only the effect of diet (FAP) with a total of 24 experimental units. Lambs were considered the random component in the model. Comparisons of means for the group of variables were evaluated using Tukey tests $(P<0.05)$.

\section{Results and Discussion}

Meat quality and acceptability are determined by its physicochemical characteristics, especially colour, appearance, flavour and tenderness. Table 2 shows the results for colour of meat. Meat lightness $\left(\mathrm{L}^{*}\right)$ and redness $\left(\mathrm{a}^{*}\right)$ did not change with diet $(P>0.05)$, or with storage of meat but yellowness $\left(\mathrm{b}^{*}\right)$ of meat increased with storage time $(P<0.01) .(P>0.05)$

Table 2 Effect of fermented apple pomace (FAP) added to diet of sheep on the colour ${ }^{1}$ of meat stored at $4{ }^{\circ} \mathrm{C}($ mean $\pm \mathrm{SD})$

\begin{tabular}{|c|c|c|c|c|c|c|c|c|}
\hline & \multicolumn{2}{|r|}{ Diet } & \multicolumn{3}{|c|}{ Time (day) } & \multicolumn{3}{|c|}{$P$ value } \\
\hline & Control & FAP & 1 & 4 & 7 & $D^{2}$ & $\mathrm{~S}^{3}$ & $\mathrm{DxS}^{4}$ \\
\hline$L^{*}$ & $33.3^{a} \pm 1.3$ & $33.2^{\mathrm{a}} \pm 1.6$ & $33.0^{\mathrm{a}} \pm 1.4$ & $33.4^{\mathrm{a}} \pm 1.3$ & $33.2^{\mathrm{a}} \pm 1.5$ & 0.81 & 0.77 & 0.94 \\
\hline$a^{*}$ & $6.9^{\mathrm{a}} \pm 0.4$ & $7.0^{\mathrm{a}} \pm 0.4$ & $6.9^{\mathrm{a}} \pm 0.4$ & $7.0^{\mathrm{a}} \pm 0.4$ & $6.9^{\mathrm{a}} \pm 0.4$ & 0.35 & 0.62 & 0.71 \\
\hline$b^{*}$ & $9.5^{a} \pm 0.6$ & $9.5^{\mathrm{a}} \pm 0.5$ & $9.2^{b} \pm 0.6 b$ & $9.6^{b} \pm 0.4$ & $9.8^{\mathrm{a}} \pm 0.5$ & 0.57 & 0.01 & 0.57 \\
\hline
\end{tabular}

Row means with different superscripts differ significantly at $P<0.05$

${ }^{1} L^{*}$ : luminosity, $a^{*}$ : redness, $b^{*}$ : yellowness

${ }^{2} \mathrm{D}$ : diet

${ }^{3}$ S: storage

${ }^{4}$ DxS: diet $x$ storage interaction

No interactions were observed between diet and storage $(P>0.05)$ for any colour parameter of the meat. These observations indicate that FAP added to sheep diet does not cause changes in the main colour parameters of meat. In addition, $L^{*}$ and $a^{*}$ values remained constant through days 1 to 7 , since differences between values were not significant. However, the colour of the meat showed a tendency to change with time of storage at $4{ }^{\circ} \mathrm{C}$, the yellowness $\left(b^{*}\right)$ of meat varied significantly through measured days. Although it remained constant until day 4 , it increased at day 7 of storage $(P<0.01)$. The typical colour of lamb or mutton varies from light red to brick red. This optimum surface colour of fresh meat is highly unstable and shortlived. it can change during storage, but this colour change alone does not mean the product is spoiled. It is well known that meat colour changes during display as myoglobin pigments in the meat surface transform on exposure to oxygen from primarily purple deoxymyoglobin to red oxymyoglobin and finally to brown metmyoglobin (Moore et al., 2003). In the present study, meat yellowness ( $b^{\star}$ ) increased during storage 
might be due to the oxidation of lipids of meat, since lipid oxidation precedes oxymyoglobin oxidation with the consequent change in colour of meat.

Post-mortem biochemical processes influence the colour of muscle foods. As the proportion of metmyoglobin increases, the meat colour turns to brown. Changes in colour during chilling storage have been observed by other authors. Vieira \& Fernandez (2014) reported an increase in the $b^{*}$ value of lamb when it was aged for five days at $\left(2 \pm 2{ }^{\circ} \mathrm{C}\right)$. Similarly, Fregonesi et al. (2014) observed that $b^{*}$ showed an increase over time $(P<0.05)$ up to 28 days when vacuum-packed lamb meat was stored under refrigeration. These authors found the highest $b^{*}$ value at 14 day of storage. In another study, Ponnampalam et al. (2013) analysed the surface brownness of meat during retail display from loin cuts of lamb stored for shorter or longer duration. They found that the aged meat was yellower than the fresh meat. These authors did not report changes in $L^{*}$ values of aged meat, but observed an increase of $a^{*}$ values in aged lamb.

Meat redness was not modified because of storage $(P>0.05)$. It has been reported that the organic acids in apples activate the secretion of gastric juices, which enhance iron absorption. Such absorption combined with myoglobin increases redness in meat (Dae et al., 2009). Moreover, the concentration of haemoproteins has been shown to increase in pigs fed apples (Muriel et al., 2002). However, in the present study, meat redness was not affected by diet $(P>0.05)$. According to Kerry et al. (2000), colour is the single most important sensory characteristic that affects consumer purchasing decisions for red meats, because consumers associate red colour with freshness (Morrissey et al., 1994). Interactions between diet and storage did not affect the colour coordinates of lamb $(P>0.05)$. In accordance with a study by Mancini \& Hunt (2005) supplementation may reduce meat colour deterioration from red to brown and reflect the myoglobin concentration and its redox state in meat.

No differences were observed between treatments $(P>0.05)$ for $\mathrm{pH}, \mathrm{WHC}$, and $\mathrm{DL}$ (Table 3 ), demonstrating that fermented apple pomace did not affect those quality parameters. The $\mathrm{pH}$ changes occurring in a carcass during the first 24 hours after slaughter are important for the quality of the final meat or meat products. The $\mathrm{pH}$ values obtained in the present study (5.19) are close to those reported for lamb 24 hours after slaughter, which normally reaches an average final pH between 5.2 and 5.8 (Lawrie \& Ledward, 2006). Abdullah \& Qudsieh (2009) observed higher pH values (5.35) in lambs of the same weight (40 $\mathrm{kg}$ live weight) than those of the present experiment. It is known that the $\mathrm{pH}$ of the longissimus muscle is higher in lambs fed grass (5.62) than lambs fed concentrate (5.57) (Brito et al., 2016). Although lambs of the present study were fed concentrate, the $\mathrm{pH}$ of their meat was even lower. Many factors can affect the final $\mathrm{pH}$ of lamb. Reported values of lamb pH are wide. They vary from 5.2 to 5.8 and there are even changes between individual animals (McGeehin et al., 2001; Texeira et al., 2005). Glycogen content in meat affects the ultimate pH of meat. However, Van Laack et al. (2001) mentioned that only $37 \%$ of the variation in ultimate $\mathrm{pH}$ can account for glycogen concentration, and that other factors affecting ultimate $\mathrm{pH}$ variation were unknown.

Water holding capacity was not affected by diet $(P<0.05)$ (Table 3). Similar results were observed by Bianchi et al. (2006) who reported that diet does not affect the WHC of lamb. WHC is one of the most important indicators of meat quality. It is defined as the ability of fresh meat to retain its own water during cutting, heating, grinding and pressing, and during transport, storage and cooking. The water released can be described as drip, purge, weep, exudate or cook loss (Huges et al., 2014). Poor WHC results in high drip and purge loss, which can represent significant loss of weight from carcasses and cuts, and may affect the yield and quality of processed meat (Aaslyng, 2002). Moreover, the presence of water in meat significantly affects the sensory properties of meat and products made of it.

Table 3 Effect of fermented apple pomace added to diet of sheep on the $\mathrm{pH}$, water-holding capacity and drip loss of meat stored at $4{ }^{\circ} \mathrm{C}$ (mean $\left.\pm \mathrm{SD}\right)$

\begin{tabular}{lccc}
\hline & & Diet & \\
\cline { 2 - 3 } & Control & & FAP \\
\hline $\mathrm{pH}$ & $5.14^{\mathrm{a}} \pm 0.13$ & $5.24^{\mathrm{a}} \pm 0.17$ & 0.18 \\
$\mathrm{WHC}(\%)^{1}$ & $64.04^{\mathrm{a}} \pm 2.41$ & $64.46^{\mathrm{a}} \pm 2.25$ & 0.70 \\
$\mathrm{DL}(\%)^{2}$ & $4.33^{\mathrm{a}} \pm 0.65$ & $4.74^{\mathrm{a}} \pm 0.88$ & 0.28 \\
\hline
\end{tabular}

Row means with different superscripts differ significantly at $P<0.05$

${ }^{1}$ WHC: water holding capacity

${ }^{2} \mathrm{DL}$ : drip loss 
Drip loss was not affected by diet $(P>0.05)$ (Table 3$)$. The observed values for DL $(4.53 \%)$ were similar to those reported as normal (Offer \& Knight, 1988). When the meat is chopped, DL is increased from $2 \%$ to $6 \%$ of the weight of the lean meat under refrigeration (Offer \& Knight, 1988). Sheridan et al. (2003) evaluated meat quality in Boer goat kids and Mutton Merino lambs and found that diet did not influence DL in the 8-9-10-rib cut within a species. D'Alesandro et al. (2013) found $2.43 \%$ of shrinkage loss in 60 -day-old lambs, being lower than those of the present study. Recently, it was reported by Budimir et al. (2018) that lamb of heavier carcasses (more than $10 \mathrm{~kg}$ ) have better WHC for raw meat and lower DL than light carcasses.

Meat tenderness (shear force) was affected by storage time $(P<0.05)$ and by diet $(P<0.05)$ (Figure 1$)$. The initial shear force (toughness) of FAB meat was higher $(3.08 \mathrm{~kg})$ than that of control meat $(2.80 \mathrm{~kg})$. However, after 6 days of storage at $4{ }^{\circ} \mathrm{C}$, the tenderness of meat from both diets was similar $(2.00 \mathrm{~kg} ; P$ $>0.05$ ). Although there was a significant difference in the initial meat tenderness between control and $F A B$ treatments, all values observed were within the acceptable range for lambs. Shorthose et al. (1986) reported that samples of lamb meat with shear force values of $5 \mathrm{~kg}$ or less were considered acceptably tender by Australian consumers. Therefore, the meat of the present study could be considered tender.

Tenderness appears to be the most important sensory characteristic of meat and a predominant quality determinant. Factors that affect meat tenderness include breed, nutrition, age and muscle location. Nutrition influences tenderness principally through its effects on the amount and type of fat in the meat. Postmortem storage or ageing of meat is the conventional practice used to tenderize meat. Vieira \& Fernandez (2014) observed a decrease of $1 \mathrm{~kg}$ in shear force of lamb aged for five days at $2{ }^{\circ} \mathrm{C}$. Increasing ageing time was reported to cause a reduction in meat toughness. Physical weakening of structures in the meat, cellular and sub-cellular damage, the release of lysosomes and other proteases, and an increase in protease activity, as well as the muscle protein denaturation at elevated temperatures and low $\mathrm{pH}$, could account for the tenderness of meat. Shear force values of lamb are between 1.84 to $5.0 \mathrm{~kg}$ on concentrate, but shear force can go up to $8.7 \mathrm{~kg}$ if sheep are on grasslands (Ramirez-Retamal \& Morales, 2014). Clelland et al. (2018) carried out research with 377 purebred Texel, males and females, and observed shear force values between 2.82 and $3.73 \mathrm{~kg}$, whereas Monteschio et al. (2018) reported a mean of shear value of $3.65 \mathrm{~kg}$ for wethers of similar weight $(40 \mathrm{~kg})$ to those used in the present study.

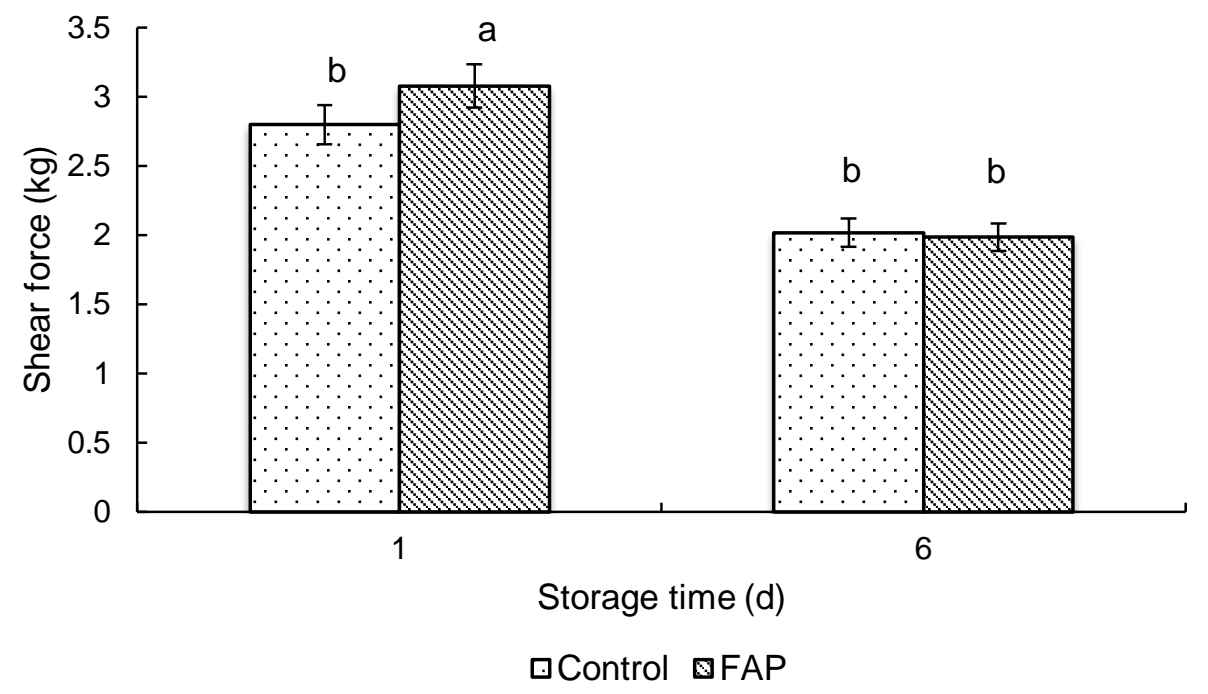

Figure 1 Effect of fermented apple pomace (FAP) added to diet of sheep on the shear force of meat stored at $4{ }^{\circ} \mathrm{C}($ mean $\pm \mathrm{SD})$

Oxidation of meat lipids or TBARS level was measured as malonaldehyde content (MAD) $(\mu \mathrm{g} / \mathrm{kg})$ of the meat (Figure 2). Diet and storage time affected $(P<0.05)$ MAD content. The interaction of diet and days of storage was significant. Similar values of MDA were observed at day 1 of storage for meat from both diets (FAP and control). However, from day 3 onwards, animals fed FAP showed lower oxidation values than those of meat from animals fed the control diet $(P<0.05)$. Natural antioxidants are commonly used in the animal industry and have positive effects on meat oxidation. 


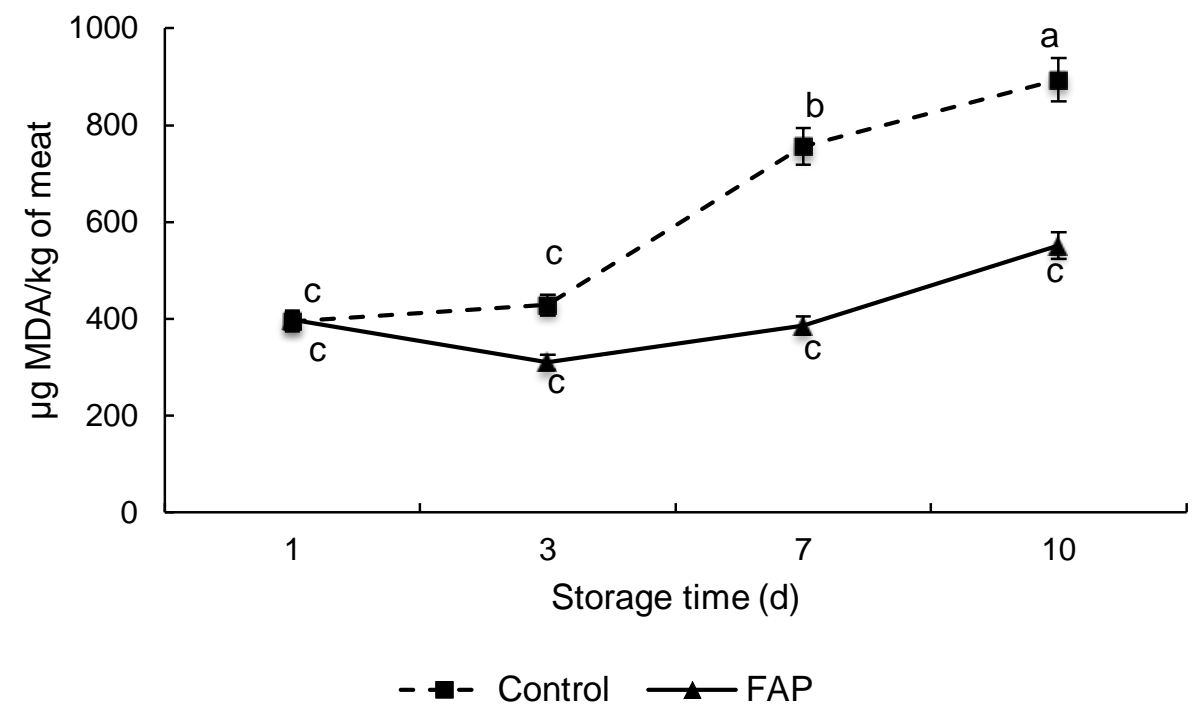

Figure 2 Effect of fermented apple pomace (FAP) added to diet of sheep on lipid oxidation ( $\mu \mathrm{g} \mathrm{MDA} / \mathrm{kg}$ ) of meat stored at $4{ }^{\circ} \mathrm{C}($ mean $\pm \mathrm{SD})$

MDA: malonaldehyde

Means with different letters are statistically different (Tukey, $P<0.05$ )

Luciano et al. (2009) found that the tannins (from Schinopsis lorentzii, a hard wood tree from Argentina), had no significant effect on lipid oxidation of meat from lambs fed this diet. However, during storage, the lipid oxidation of meat from lambs fed the tannin-rich diet decreased. Lipid oxidation products accelerate haemeprotein oxidation, resulting in a positive correlation between metmyoglobin formation and lipid oxidation (Faustman et al., 1999). Long ageing also leads to high TBARS levels (measured as MDA), suggesting a product that is likely to exhibit rancidity and off flavours from lipid oxidation (Ponnampalam et al., 2013).

Post-mortem biochemical processes are active during retail and storage, and they influence the colour of muscle foods. As the proportion of metmyoglobin increases, meat colour turns to brown. This induces a negative response in consumers. When the proportion of metmyoglobin reaches $20 \%$, it has been found that the product is rejected by half of the potential consumers (Renerre \& Mazuel, 1985). After the intake of plantfood by-products, such as apple pomace, the antioxidant activity in muscle increases (Guil-Guerrero et al., 2016). As well as the antioxidant effect of apple pomace (Lu \& Foo, 2000), it has antibacterial, antiviral and anti-inflammatory properties (Yue et al., 2012).

Numerous studies have reported that the polyphenols responsible for the antioxidant activity in apple are still present in the pomace (Gazalli et al., 2014) and in apple peel (Shanmugam et al., 2017). These activities can be up to 30 times better than those of the antioxidant vitamins $C$ and $E$. Therefore, apple pomace can provide an inexpensive source for food fortification (Foo \& Loo, 1999). Several minerals and vitamins are antioxidative, and their roles in protecting the muscle tissue from structural damage are well established (Hercberg et al., 2004). Apple pomace has already been included in the formulation of several meat products (Verma et al., 2010) without changes in overall palatability (Rather et al., 2015).

\section{Conclusion}

Based on the results in the present study, it can be concluded that fermented apple pomace (FAP) can replace $11 \%(D M)$ of alfalfa hay and soybean meal in sheep diet with an improvement in meat quality. Loin meat from sheep fed FAP will exhibit less oxidation of lipids after storage at $4{ }^{\circ} \mathrm{C}$, while it retains good quality in terms of colour, $\mathrm{pH}, \mathrm{WHC}, \mathrm{DL}$ and tenderness. The decrease of lipid oxidation in meat reflects the benefits of the antioxidant potential of FAB components. Utilization of apple juice by-products in sheep nutrition could improve profitability and valorization of local agricultural wastes since feeding FAP to sheep is an efficient way to produce high-quality meat with longer shelf life. 


\section{Authors' Contributions}

$\mathrm{VL}$ is a master's student, who conducted the experiment. ADAR is the mentor, who was in charge of conception and design, and LCL \& HJ did chemical and data analysis and prepared the manuscript.

\section{Conflict of Interest Declaration}

The authors have declared no conflict of interest.

\section{References}

Aaslyng, M.D., 2002. Quality indicators for raw meat. In: J.P. Kerry, J.F. Kerry \& D. Ledward (eds.). Meat Processing. Woodhead, Cambridge, UK. pp. 157-174.

Abdullah, A.Y. \& Qudsieh, R.I., 2009. Effect of slaughter weight and aging time on the quality of meat from Awassi ram lambs. Meat Sci. 82, 309-316.

Alibes, X., Muñoz, F. \& Rodríguez, J., 1984. Feeding value of apple pomace silage for sheep. Anim. Feed Sci. Technol. 11, 189-197.

Antonomanolaki, R.E., Vareltzis, K.P., Georgakis, S.A. \& Kaldrymidou, E., 1999. Thermal gelation properties for surimilike material made from sheep meat. Meat Sci. 52, 429-435.

Bianchi, G., Betancur, O., Garibotto, G., Feed, O., Franco, J. \& Sañudo, C., 2006. Efecto del tiempo de maduración postmortem sobre la calidad sensorial de la carne de corderos Corriedale y cruza. Agrociencia 10, 81-87. (in Spanish)

Brenes, A., Viveros, A., Goñi, I., Centeno, C., Sáyago-Ayerdy, S.G., Arija, I. \& Saura-Calixto, F., 2008. Effect of grape pomace concentrate and vitamin $\mathrm{E}$ on digestibility of polyphenols and antioxidant activity in chickens. Poult. Sci. 87, 307-316.

Brito, G.F., Ponnampalam, E.N. \& Hopkins, D.L., 2016. The effect of extensive feeding systems on growth rate, carcass traits, and meat quality of finishing lambs. Compr. Rev. Food Sci. Food Saf. 16, 1541-4337.

Budimir, K., Trombetta, M. F., Francioni, M., Toderi, M. \& D'Ottavio, P., 2018. Slaughter performance and carcass and meat quality of Bergamasca light lambs according to slaughter age. Small Rumin. Res. 164,1-7.

Ćetković, G., Čanadanović-Brunet, J., Djilas, S., Savatovic, S., Mandic, A. \& Tumbas, V., 2008. Assessment of polyphenolic content and in vitro antiradical characteristics of apple pomace. Food Chem. 109, 340-347.

Clelland, N., Bunger, L., McLean, K.A., Knott, S., Matthews, K.R. \& Lambe, N.R., 2018. Prediction of intramuscular fat content and shear force in Texel lamb loins using combinations of different X-ray computed tomography (CT) scanning techniques. Meat Sci. 140, 78-85.

D’Alessandro, A.G., Giuseppe Maiorano, G., Ragni, M., Casamassima, D., Marsico, G. \& Martemuccia, G., 2013. Effects of age and season of slaughter on meat production of light lambs: Carcass characteristics and meat quality of Leccese breed. Small Rumin. Res. 114, 97-104.

Dae, L.S., Yun, K.H., Jung, J.H., Yun, J.S., Chowdappa, R., Hee, H.J., Min, S.Y., Cheol, P.J., Kil, H.M. \& Kim, Ch., 2009. The effect of fermented apple diet supplementation on the growth performance and meat quality in finishing pigs. J. Anim. Sci. 80, 79-84.

De Oliveira Monteschio, J., Campos Burin, P., Leonardo, A.P., Fausto, D.A., da Silva, A.L.A., Ricardo, H.d.A., et al, 2018. Different physiological stages and breeding systems related to the variability of meat quality of indigenous Pantaneiro sheep. PLoS ONE 13 (2), e0191668. https://journals.plos.org/plosone/article?id=10.1371/journal. pone.0191668

Díaz-Plascencia, D., Rodríguez-Muela, C., Mancillas-Flores, P., Corral, G., Salvador, F., Durán, L. \& La, O.O., 2013. Producción de gas in vitro de una ración para vaca lechera suplementada con levaduras aisladas de subproductos de manzana. Cuban J. Agric. Sci. 47, 165-169. (In Spanish)

Faustman, C., Liebler, D.C., McClure, T.D. \& Sun, Q., 1999. $\alpha, \beta$-unsaturated aldehydes accelerate oxymyoglobin oxidation. J. Agric. Food Chem. 47, 3140-44.

Foo, L.Y. \& Lu Y., 1999. Isolation and identification of procyanidins in apple pomace. Food Chem. 64, 511-518.

Fregonesi, R.P., Portes, R.G., Aguiar, A.M.M., Figueira, L.C., Gonçalves, C.B., Arthur, V., Lima, C.G., Fernandes, A.M. \& Trindade, M.A., 2014. Irradiated vacuum-packed lamb meat stored under refrigeration: Microbiology, physicochemical stability and sensory acceptance. Meat Sci. 97, 151-155.

Garrido, M.D., Bañón, S., Pedauyé, J. \& Laencina, J., 1994. Objective meat quality measurements of ham: A practical classification method on the slaughterline. Meat Sci. 37, 421-428.

Gazalli, H., Malik, A.H., Sofi, A.H., Wani, S.A., Pal, M.A., Mir, A. \& Ashraf, H., 2014. Nutritional value and physiological effect of apple pomace. Int. J. Food Nutr. Saf. 5, 11-15.

Gómez-Vázquez, A., De la Cruz-Lázaro, E., Pinos-Rodríguez, J.M., Guerrero-Legarreta, I., Plascencia-Jorquera, A. \& Joaquin-Torres, B.M., 2011. Growth performance and meat characteristics of hair lambs grazing stargrass pasture without supplementation or supplemented with concentrate containing different levels of crude protein. Acta Agric. Scand. Sect. A - Anim. Sci. 61, 115-120.

Guil-Guerrero, J.L., Ramos, L., Moreno, C., Zúñiga-Paredes, J.C., Carlosama-Yepez, M. \& Ruales P., 2016. Plant-food by-products to improve farm-animal health. Anim. Feed Sci. Technol. 220, 121-135.

Hercberg, S., Galan, P., Preziosi, P.S., Bertrais, S., Mennen, L., Malvy, D., Roussel, A.M., Favier A. \& Briançon, S., 2004. The SU.VI.MAX study: A randomized, placebo-controlled trial of the health effects of antioxidant vitamins and minerals. Arch. Int. Med. 164, 2335-2342.

Honikel, K.O. \& Jim, C.J., 1986. Causes of the development of PSE pork. Fleischwirtschaft 66, 349-351.

Hughes, J.M., Oiseth, S.K., Purslow, P.P. \& Warner R.D., 2014. A structural approach to understanding the interactions between colour, water-holding capacity and tenderness. Meat Sci. 98, 520-532. 
Kerry, J.P., O'Sullivan, M.G., Buckley, D.J., Lynch, P.B. \& Morrissey, P.A., 2000. The effects of dietary a-tocopheryl acetate supplementation and modified atmosphere packaging (MAP) on the quality of lamb patties. Meat Sci. 56, 61-66.

Kim, H.Y., Song, Y.M., Kang, Y.S., Kim, C.H., Lee, S.D., Chowdappa, R., Ha, J.H. \& Kang, S.M., 2006. The effect of fermented persimmon shell diet supplementation on the growth performance and blood parameters in pigs. J. Anim. Sci. 77, 314-319.

Kim, Y.H., Nam, K.C. \& Ahn, D.U., 2002. Color, oxidation-reduction potential, and gas production of irradiated meats from different animal species. J. Food Sci. 67, 1692-1692.

Lawrie, R.A. \& Ledward, D.A., 2006. Lawrie's Meat Science. CRC. 7th English edition. Woodhead and CRC Press, Cambridge, England. 442 pp.

Lu, Y. \& Foo, L.Y., 2000. Antioxidant and radical scavenging activities of polyphenols from apple pomace. Food Chem. $68,81-85$.

Luciano, G., Monahan, F.J., Vasta, V., Biondi, L., Lanza, M. \& Priolo, A., 2009. Dietary tannins improve lamb meat colour stability. Meat Sci. 81, 120-125.

Mancini, R.A. \& Hunt, M.C., 2005. Current research in meat color. Meat Sci. 71, 100-121.

McGeehin, B., Sheridan, J.J. \& Butler, F., 2001. Factors affecting the pH decline in lamb after slaughter. Meat Sci. 58, 79-84.

Mirzaei-Aghsaghali, A. \& Maheri-SIS, N., 2008. Nutritive value of some agro-industrial by-products for ruminants - A review. Wrld J. Zool. 3, 40-46.

Moore, M., Han, I., Acton, J., Ogale, A., Barmore, C. \& Dawson, P., 2003. Effects of antioxidants in polyethylene film on fresh beef color. J. Food Sci. 68, 99-104.

Morrissey, P.A., Buckley, D.J., Sheehy, P.J.A. \& Monahan, F.J., 1994. Vitamin E and meat quality. P. Nutr. Soc. 53, 289-295.

Muriel, E., Antequera, T. \& Ruiz, J., 2002. Efecto del tipo de músculo sobre los parámetros de calidad en carne fresca de cerdo ibérico. Cien. Tecnol. Alim. 3, 241-247. (in Spanish).

NRC, 1985. National Research Council. Nutrient Requirements of Sheep. 6th revised edition. National Academic Press. Washington, DC.

O'Shea, N., Ktenioudaki, A., Smyth, T.P., McLoughlin, P., Doranm, L., Auty, M.A.E., Arendt, E. \& Gallagher, E., 2015. Physicochemical assessment of two fruit by-products as functional ingredients: Apple and orange pomace. J. Food Eng. 153, 89-95.

Offer, G. \& Knight, P., 1988. The structural basis of water holding in meat. Part 2: Drip losses. In: R.A. Lawrie (ed). Development in meat science-4. Elsevier Science, London.

Olfaz, M., Ocak, N., Erener, G., Cam, M.A. \& Garipoglu, A.V., 2005. Growth carcass and meat characteristics of Karayaka growing rams fed sugar beet pulp, partially substituting for grass hay as forage. Meat Sci. 70, 7-14.

Piccini, J.L., Evans, D.R. \& Quaranta, H.O., 1986. Comparison of TBA number of irradiated fish with sensory quality. Food Chem. 19, 163-171.

Ponnampalam, E.N., Butler, K.L., Burnett, V.F., McDonagh, M.B., Jacobs, J.L. \& Hopkins D.L., 2013. Aged vacuum packaged lamb cuts are less brown than fresh muscle cuts under simulated retail display. Food Nut. Sci. 4, 147-153.

Ramirez-Retamal, J. \& Morales, R., 2014. Influence of breed and feeding on the main quality characteristics of sheep carcass and meat: A review. Chilean J. Agric. Res. (online). 74, 225-233.

Rather, S.A., Akhter, R., Masoodi, F.A., Gani, A. \& Wani, S.M., 2015. Utilization of apple pomace powder as a fat replacer in goshtaba: A traditional meat product of jammu and kashmir, India. J. Food Meas. Charact. 9, 389-399.

Renerre, M. \& Mazuel, J.P., 1985. Relationships between instrumental and sensory measurement methods of meat color. Sci. Alim. 5, 541-557.

Rodríguez, M.C., Rodríguez-Ramírez, H.E., Díaz-Plascencia, D., Bocourt-Salabarría, R. \& Arzola-Álvarez, C., 2017. Concentration of acid detergent fiber, neutral detergent fiber and lignin during solid state fermentation of apple (Malus domestica) derivates. Cuban J. Agric. Sci. 51, 47-60.

SAS, 1999. Statistical analysis systems. User's guide. Statistics, version 8. SAS Institute, Inc. Cary, NC. U.S.A.

Shanmugam, S., Monis, S.A., Roy, N., Sruthi, D., Mithra, A. \& Swamy G.J., 2017. Effect of antioxidants and dietary fiber from apple and strawberries on value addition into mutton patties. Annals of the University of Dunarea de Jos of Galati. Fascicle VI. Food Technol. 41, 95-105.

Sheridan, R., Hoffman, L.C. \& Ferreira, A.V., 2003. Meat quality of Boer goat kids and Mutton Merino lambs. 2. Sensory meat evaluation. Anim. Sci. 76, 73-79.

Shorthose, W.R., Powell, V.H. \& Harris, P.V., 1986. Influence of electrical stimulation, cooling rates and ageing on the shear force values of chilled lamb. J. Food Sci. 51, 889-928.

Simitzis, P.E., Deligeorgis, S.G., Bizelia, J.A., Dardamani, A., Theodosiou, I. \& Fegeros, K., 2008. Effect of dietary oregano oil supplementation on lamb meat characteristics. Meat Sci. 79, 217-223.

Sudha, M.L., Baskaran, V. \& Leelavathi, K., 2007. Apple pomace as a source of dietary fiber and polyphenols and its effect on the rheonological characteristics and cake making. Food Chem. 104, 686-692.

Taasoli, G. \& Kafilzadeh, F., 2008. Effects of dried and ensiled apple pomace from puree making/ on performance of finishing lambs. Pakistan J. Biol. Sci. 11, 294-297.

Teixeira, A., Batista, S., Delfa, R. \& Cadavez, V., 2005. Lamb meat quality of two breeds with protected origin designation. Influence of breed, sex and live weight. Meat Sci. 71, 530-536.

Tsai, T.C. \& Ockerman, H.W., 1981. Water binding measurement of meat. J. Food Sci. 43, 697-701. 
Van Laack, R.L.J.M., Kaufmann, R.G. \& Greaser, M.L., 2001. Determinants of ultimate pH of meat. Future of meat: Congress proceedings of the 47th International Congress of Meat Science and Technology, Kraków, Poland, August 26-31, 2001. (pp. 22-26).

Van Soest, P.J., Robertson, P.J. \& Lewis, B.A., 1991. Methods for dietary fiber, neutral detergent fiber, and non-starch polysaccharides in relation to animal nutrition. J. Dairy Sci. 74, 3583-3597.

Vázquez, S.E.T., Partida, P.J.A., Rubio, L.M.S. \& Méndez, M.D., 2011. Comportamiento productivo y características de la canal en corderos provenientes de la cruza de ovejas Katahdin con machos de cuatro razas cárnicas especializadas. Rev. Mex. Cienc. Pecu. 2, 247-258. (in Spanish)

Verma, A.K., Sharma, B.D. \& Banerjee, R., 2010. Effect of sodium chloride replacement and apple pulp inclusion on the physico-chemical, textural and sensory properties of low-fat chicken nuggets. LWT Food Sci. Technol. 43, 715-719.

Vieira, C. \& Fernandez, A.M., 2014. Effect of ageing time on suckling lamb meat quality resulting from different carcass chilling regimes. Meat Sci. 96, 682-687.

Yue, T., Bai, X., Zhang, H. \& Yuan Y., 2012. Fractionation and anti-inflammatory effects of polyphenol-enriched extracts from apple pomace. Bangladesh J. Pharmacol. 7, 28-32. 